\title{
A FAILURE TO IMPOSE CONTROL: PRIVATE SECURITY AND THE MEXICAN STATE
}

\author{
Logan Puck
}

${ }^{a}$ Visiting Assistant Professor of Politics at Bates College. Lewiston, Maine, EUA.

E-mail: Ipuck@bates.edu

ORCID: 0000-0002-6417-4902

http://dx.doi.org/10.1590/0102-029068/114

\section{Introduction}

The private security industry is growing rapidly across the globe and governments are implementing numerous strategies to attempt to control it. Scholars tend to agree that drafting and imposing comprehensive regulations is one of the most effective strategies states can use to control and direct private security companies to reduce insecurity and operate effectively, safely, and accountably. A number of studies on private security tend to highlight and rightfully so - the weaknesses or absence of states' private security regulations (Argueta, 2012; Born; Buzatu, 2008; Lopes, 2018; McCrie, 2017; Nagaraj, 2012; Simelane, 2008). However, strengthening a regulatory regime is not sufficient for solving many problems plaguing the private security industry and can even be counterproductive if state institutions are weak.

In this essay, I explore how attempts to strictly regulate private security firms at the federal and state level have failed to rein in the industry in Mexico. The Federal government of Mexico, Mexico City, and every state have developed some form of regulation to control the activities of 
the private security industry. Although varied from state to state, these regulations are quite comprehensive, detailed, and stringent in states with the largest number of private security providers. In this study, I argue that these strict laws have limited the State's ability to effectively impose control over the industry. First, the complicated, expensive, and time-consuming registration process and requirements to remain in good standing are too high a barrier to entry for potential firms. Second, government officials and bureaucrats may use their power as gatekeepers to extract bribes and restrict access to private security and weapons licenses to friends and associates. Third, weak enforcement of private security regulations due to corruption and a lack of political will disincentivizes companies from abiding by the law. These factors led to a widespread regulation evasion, which has in turn created an expansive market of unregulated and undisciplined private security companies that fur30 ther contribute to disorder and insecurity.

I base my findings on a qualitative research design focused on three subnational cases, - Mexico City, Jalisco, and Nuevo León. I analyze the regulations of each state and their consequences based on data collected from government documents, archival materials, and interviews with representatives from Mexico's security field.

To assess the attempts of the Mexican government to regulate the private security industry, this essay will discuss the literature on private security regulations, examine competing theories on regulations and show how the Mexican case aligns more closely with the public choice theory as opposed to the public interest theory. After presenting a brief history of private security regulations in Mexico, I apply a model to assess their quality and scope. Finally, I describe how and why these regulatory efforts have failed to successfully rein in the industry, reinforcing the weakness of Mexican state institutions. 
The literature on private security regulations tends to be centered on the Global North, providing rich insights about the political process and motives behind the creation of or resistance to regulations (Bure 2015; Smith; White 2014; White, 2010; Zedner 2006), the type and quality of regulations in individual countries (Button, 2011; Hemmens et al., 2001; McCrie, 2017; Nalla; Crichlow, 2017) and comparatively across countries (Button, 2012; Button; Stiernstedt, 2017; Button; Stiernstedt, 2018; Leloup; White, 2021; Prenzler; Sarre, 2008; White, 2014; Scheerlinck et al., 2020a; Scheerlinck et al., 2020b; Waard, 1999), as well as the best practices and regulatory frameworks for the industry (Button et al., 2019; Button; George, 2006; Prenzler; Sarre, 2008).

When compared with many areas of the Global South, the Global North tends to possess higher state capacity and lower corruption, crime, and violence levels. Therefore, states in the Global South face different and greater challenges when confronting the private security industry. Likewise, the issue of regulation takes on higher stakes as private security providers have greater potential to significantly exacerbate inequality and insecurity. In Latin America, for example, the murder rate is higher than in any other region in the world; police forces are often widely disrespected for poor effectiveness and abusive and corrupt behavior; and government bureaucracies, often rife with corruption, struggle to serve the citizenry. Nevertheless, the literature on private security regulations in the Global South, and especially Latin America, lags behind that in the Global North, thus demanding greater attention. the recently published edited volume Regulating the Security Industry: Global Perspectives (Nalla; Prenzler, 2018), which does an excellent job compiling research on regulatory regimes in the United States, Western and Eastern Europe, Oceania, East Asia, and Africa, while completely disregarding Latin America. 
While the literature on private security in Latin America is slowly growing, few studies focus directly on regulations (some exceptions include Lopes; Moraes, 2018 and Perret, 2013). Much of the literature on private security in Latin America describes the emergence of the industry and its current make-up in either a single country (Argueta 2013; Huggins, 2000; Muller, 2010; Solar, 2019; Wood; Cardia 2006) or multiple countries in the region (Ungar, 2007-2008). Although critically valuable for understanding how and why the industry has grown in Latin America and its various manifestations across the region, most of these texts include a relatively brief discussion of regulations that tend to rightly emphasize rampant informality within the industry. Generally, these texts either highlight a country's lack of sufficient private security regulations (see Argueta, 2013; Solar, 2019) or weak state enforcement of regulations (Muller, 2010; Perret, 2013) or else the link is mentioned but not deeply explored 32 (Huggins, 2000; Wood; Cardia, 2006).

Reports on private security in Latin America provide useful insights on the state of regulations and the challenges faced by many countries in the region; however, they tend to lack theoretical development (see DCAF, 2016; Kinosian; Bosworth, 2018; Robert Strauss Center, 2018). While countries such as Chile and Guatemala possess outdated and insufficient regulatory regimes, other countries in the region such as Mexico and Brazil possess relatively strict private security laws, but also high levels of informality. Focusing on the case of Mexico and relying on the tollbooth variant of the public choice theory, this study analyzes the link between strict regulations and weak enforcement - which has created a chaotic security market where informality reigns.

\section{Theories of regulation and private security}

One of the primary debates within the literature on regulations contemplates governments' motivations and 
consequences, which splits many scholars into two diametrically opposed camps: public interest theorists and public choice theorists. Formulated by English economist Arthur Cecil Pigou, the public interest theory posits that regulations are imposed by able and benevolent governments to serve the public interest by remedying market failures, particularly monopolistic behavior, and negative externalities. Pigou explains that "in any industry, where there is reason to believe that free play of self-interest will cause an amount of resources to be invested different from an amount that is required in the best interest of the national dividend, there is a prima facie case for public intervention” (1938, p. 331). Government regulations are assumed to be costless and, therefore, the most logical and effective mechanism for creating a more equitable and efficient market. Examples of poor regulatory performance are written off as cases of bad management that can be remedied with more experience (Posner, 1974; Shleifer 2005; Stigler, 1970). Scholars of private security tend to align with the public interest theory by arguing that imposing and enforcing regulations is the most effective tool for controlling burgeoning private security industries within a state's borders and promoting "optimal security" (Button, 2012, p. 204). Despite some exceptions (Argueta, 2012; Muller, 2010), most studies on the field fail to consider the downside to imposing more regulations on the industry, thus exhibiting an implicit bias towards the public interest theory.

On the other hand, the public choice theory "sees the government as less benign and regulation as socially inefficient" (Djankov et al, 2002, p. 2). Inspired by Mancur Olson's (1965) logic of collective action, this theory argues that regulations solely benefit the interests of specific groups (Farber and Frickey, 1991; Hantke-Domas, 2003). Although generally credited to George Stigler 
(1971; 1974), Posner (1974) and Peltzman (1976) were other important early contributors to the theory. The original variant is Stigler's "capture theory" - which argues that "as a rule, regulation is acquired by the industry and is designed and operated primarily for its benefit" (Stigler, 1971, p. 1). More specifically, economic entities manipulate the political system to obtain regulations designed for their own benefit and often to the detriment of the public interest.

Industries have lower collective action costs because they tend to have homogenized interests and a greater stake in the regulatory process than a diffuse public with varying interests, less access to information, and a lower overt stake in the issue. They are better equipped to influence political representatives to pass legislation that is favorable to their interests and alter regulations that have already passed (Etzioni, 2009; Posner 1974). For example, industries may dilute, repeal, and weaken enforcement of existing regulations and/or manipulate and switch regulators (Etzioni, 2009).

A new variant of the public choice theory emerged in the late 1980s and 1990s, shifting the focus from the interests of industries to those of state actors. Dubbed by Djankov et. al. as the "tollbooth view," this approach initially developed by McChesney (1987) and De Soto (1989) "holds that regulation is pursued for the benefit of politicians and bureaucrats" (Djankov et al, 2002, p. 3). According to this view, politicians and bureaucrats develop and enforce regulations s to wield power over those seeking access to the industry being regulated, thus profiting off the industry by demanding bribes to access to the sector in question. Such a view also poses that "more extensive regulation should be associated with socially inferior outcomes, particularly corruption" (p. 3). 
Djankov et al. (2002) conducted a study on entry regulations with 85 countries, ${ }^{1}$ verifying that countries with more regulations tend to be more corrupt and possess much larger informal economies. According to their findings, strict and copious entry regulations in these situations rarely succeed at fulfilling the intended positive social outcomes. Glaeser and Shliefer (2003) explain that "countries with more regulations of entry exhibit higher corruption and larger unofficial economies, but not superior social outcomes that regulation allegedly aims for" (p. 420).

The public choice theory functions as a guide for the Mexican case. Stringent Mexican regulations and the high costs to abide by them has allowed politicians and bureaucrats in the federal and state governments to use the tollbooth approach by rewarding associates with expedited private security licenses, reduced costs, and limited supervision. Simultaneously, these actors create high barriers for non-connected firms by demanding expensive fees, bribes, and/or delaying registration process. In an environment of widespread informality and corruption, Mexican private security owners have been disincentivized to properly register their firms and abide by state and federal regulations. However, before delving into the problems, I will first recount the history of regulatory regimes in Mexico and their current make-up.

\section{Private security regulations in Mexico}

In 1948, the Federal government of Mexico passed its first private security legislation, the Reglamento para los Investigadores, Detectives y Policías Privados o pertenecientes a Organismos de Servicio Público Descentralizado o Concesionado (Regulations for Investigators, Detectives and Private Police

\footnotetext{
1 Entry regulations refers to legal requirements imposed upon businesses attempting to enter an industry.
} 
or those Belonging to Decentralized or Licensed Public Service Agencies). Primarily applied to private detectives and private policing units tasked with guarding public institutions, the regulations were relatively rudimentary and lacked width and depth - despite including some registration, hiring, and uniform requirements.

In 1985, President Miguel de la Madrid repealed and decreed this legislation unconstitutional for violating Article 21, which states that public policing is the exclusive right of the Mexican state and, therefore, cannot be delegated or licensed to private individuals (México, 1985; Universal, 1984a). Despite the decree, private security companies were only barred from performing police functions and using the term policia in their documentation, identification, or company name. Firms complying with these rules were permitted to continue operating (México, 1985). As the abrogated 1948 legislation was not replaced by a new federal private security law until 2006, states had to formulate their own private security regulations.

Due to the massive growth of the private security industry during in the 1990s, the Federal District and Mexican states began formulating their own private security regulations. The growth in private security provision in Mexico peaked in 1999, showing a $40 \%$ increase compared to the year before (Muller, 2010). By 2000, over 1,400 private security companies were registered with the federal government and many more operated informally. Be it specific private security codes or regulations within public security laws, today, every Mexican state has some type of private security regulation. In the following section, I classify regulatory regimes using a modified version of the model proposed by Button and George to show how private security law and regulations of the Federal government and of states with cities with the highest number of private security companies - Mexico City, Guadalajara, Jalisco, 
and Monterrey Nuevo León - are quite comprehensive and generally wide in scope.

\section{Assessing Private Security Regulations in Mexico}

Currently, we still lack internationally agreed upon standards for private security regulatory frameworks. In 2008, "The Montreux Document" outlined a set of good practices and standards for the private security industry, focusing on the practices of private military and security companies in armed conflict zones. The document was ratified by 54 states, including four from Latin America, but not Mexico, for its scope was not entirely applicable to private security companies operating in non-military contexts. Despite the lack of an international agreement for private security companies engaged in non-military-related activities, scholars, practitioners, and international governmental organizations have endeavored to develop standards and best practices applicable specifically to this sector. To assess the regula-

tions in Mexico, I rely on a rubric developed by Button and George (2006) for analyzing the quality and depth of statutory private security regulations, incorporating elements from more recent research to update the framework.

\section{Scope of coverage}

Button and George (2006) analyze regulations along two spectrums - "width and depth". Regulations width is defined as "the extent to which the different sectors of the private security industry are regulated" (2006, p. 567). The field of private security is quite broad and includes a variety of sectors. A wide regulatory model includes at least two sectors of the industry, such as security consultants and security equipment installers (2006). Prenzler and Sarre (2008) reinforce and expand on the need for wide coverage, advocating for comprehensive licensing that covers "all occupations involved in security work" (p. 24). 
Table 1

Width of Regulations

\begin{tabular}{|c|c|c|}
\hline & Narrow & Wide \\
\hline $\begin{array}{c}\text { Scope of } \\
\text { Coverage }\end{array}$ & $\begin{array}{c}\text { Manned Security Services, } \\
\text { Private Investigators }\end{array}$ & $\begin{array}{c}\text { Manned Security Services, Private } \\
\text { Investigators, Security Consultants, } \\
\text { Installers of Security Equipment, } \\
\text { and beyond }\end{array}$ \\
\hline
\end{tabular}

Source: Adapted from George and Button, 1997, p. 191-192

Despite not covering every occupation connected to security work, Mexican regulations tend to have a wide scope that account for many different private security sectors. Regulations from the federal government and Nuevo León cover seven private security sectors, whereas those from Mexico City cover five (México, 2014; México, 2011; Nuevo León, 2021). By casting a large coverage net, these regulations ensure that all (or at least most) forms of private security provision are accounted for, monitored, and directed by the state. Among the states under study, Jalisco is the only one with narrower coverage, addressing manned security services, goods transfer protection, and custody and surveillance of goods (Jalisco State Government, 2004).

\section{Table 2}

Width of Regulations Applied to Mexican Cases

\begin{tabular}{|c|c|c|c|c|}
\hline & $\begin{array}{c}\text { Federal } \\
\text { Government }\end{array}$ & Mexico City & Jalisco & Nuevo León \\
\hline $\begin{array}{c}\text { Scope of } \\
\text { Coverage }\end{array}$ & Wide & Wide & Narrow & Wide \\
\hline
\end{tabular}

\section{Depth of coverage}

Depth of regulations are defined as "the number and type of regulations to be met by private security firms and employees" (George; Button, 2006, p. 567). Governing bodies 
may impose "minimal" to "comprehensive" requirements for firms and individuals seeking to obtain and retain a private security operator's license. George and Button (2006) distinguish between two main types of private security regulations: (1) those "that seek to address the character of employees, owners, etc.;" and (2) those "that seek to enhance the quality of security provision through minimum standards of training and operation” (p. 568). A comprehensive regulatory system must cover both regulations types and apply them to private security firms and employees. Prenzler and Sarre (2008), Button and Siternstedt (2017), and the UNODC (2014) provide important additions to the model proposed by Button and George (2006), included below in italics.

\section{Table 3}

Depth of Regulations

\begin{tabular}{|l|}
\hline Comprehensive Regulatory System \\
\hline Entrance Requirements for Firms to Enter Industry \\
a) Payment of Fee for License \\
b) Restrictions on Background of Owner/Qualifying Agent \\
c) Minimum Experience/Qualifications of Owner/Qualifying Agent \\
d) Minimum Training for Owner/Qualifying Agent \\
e) Passing of Examination of Owner/Qualifying Agent \\
f) Fingerprinting of License Applicants \\
\hline Entrance Requirements for Individuals to Work in Industry \\
a) Payment of Fee for License/Registration \\
b) Restrictions on Background of Employees \\
c) Minimum Training for Employees \\
d) First Aid Certification \\
e) Passing of Examination by Employees \\
f) Drug and Alcoho/ Testing Programs \\
g) Requirement or Refresher/Specialist Training \\
Minimum Standards of Operation \\
a) Bonding/Insurance \\
b) Facilities/Equipment \\
c) Other Standards \\
d) Code of Conduct \\
e) Use of Force Guidelines \\
f) Police Cooperation
\end{tabular}

Source: Adapted from George and Button, 1997, p.193; Prenzler and Sarre, 2008; George and Stiernstedt 2017; UNODC 2014. 


\section{Entrance requirements for firms}

Mexican private security regulations tend to follow some of the entrance requirements for firms, but not all. In all cases, paying a license fee is required. Although some regulations do require minimum experience and restrictions on the background of the owner or qualifying agent, these tend to be vague and/or somewhat minimal. Most of the regulations simply demand that firm owners or qualifying agents must possess Mexican citizenship and provide evidence of possessing the human, technical, financial and material means to provide private security services. Nuevo León, Mexico City, and Jalisco require firm owners to undergo fingerprinting (Jalisco State Government, 2014; México, 2011; México, 2014; Nuevo León, 2021). Moreover, only the federal regulations require owners/ qualifying agents to possess minimal training and none of the regulations mention the need for owners/qualifying agents to pass an examination (México, 2011).

\section{Entrance requirements for individuals}

Individual entrance requirements are much more comprehensive than those for firm owners. None of the regulations mention the need for paying a fee to work in the private security industry; however, hiring requirements are included in all of them. All regulations require background check to confirm that potential hires do not have a criminal record or are current members of the armed forces or the police. Moreover, anyone dishonorably discharged from the armed services or a public security force is prohibited from working for a private security company. Before hiring, Mexico City and Jalisco require applicants to pass a medical and drug tests (Jalisco State Government, 2014; México, 2014), and Mexico City's regulations also mandate psychological and lie detector tests. Furthermore, medical, psychological, and drug tests 
must be administered annually to all personnel (México, 2014). Although not mandatory during the hiring process, Nuevo León requires all operative personnel to take medical, psychological, and toxicology exams annually once they have been employed by a firm (Nuevo León, 2021). None of the regulations mandate first aid certification or alcohol tests.

All the regulations require some form of personnel training, either laying out a specific training regimen that all companies must enact or requiring employees to receive training at the state police academy. The training guidelines of Mexico City, for example, are quite rigorous, and employees must undergo evaluation after completing each training session (México, 2014). Overall, private security guards are expected to receive approximately 80 hours of training immediately after enrollment and periodic training throughout their careers, as well as annual accreditation (Arámbula, 2014; México, 2014). Although below the European average, 80 training hours is far above the requirements for several countries in the region, including Germany, Switzerland, Bulgaria, Italy, and the United Kingdom (CoESS, 2015). In Nuevo León, employees must receive training at the University of Security Sciences or at private training centers approved by La Dirección de Control y Supervisión a Empresas y Servicios de Seguridad Privada. In turn, to ensure that all personnel are subjected to the training regimen desired by the state, private security employees in Jalisco are instructed at the State police academy (Ibarra, 2014; Jalisco State Government, 2014; Nuevo León, 2021).

\section{Minimum standards of operation}

In general, the regulations cover most of the criteria established by George and Button (2006) for minimum standards of operation. According to Mexico City and 
Jalisco, firms must possess insurance policies that guarantee payment to clients for any damages caused during their services. All the regulations address facilities and tend to be quite strict in regard to equipment. To ensure everything has been registered and is working properly, facilities and equipment undergo annual inspections. The regulations also specify that uniform colors, logos, and emblems must be different from those used by the police and armed forces and vehicles, cannot be similar to those used by public security forces nor be equipped with sirens.

Some regulations are much more specific and detailed. In Mexico City, for example, vehicles must display their denomination, logo, ID number, permit and authorization number, and the words seguridad privada. The letters and numbers must be at least fifteen centimeters high and seven centimeters wide (México, 2014). Metal badges are prohibited. Stripes on shirtsleeves and along the sides of pants must contrast in color (México, 2014). In Jalisco, private security personnel must wear a white shirt with the company logo located on their left sleeve five centimeters below the seam on the left shoulder of the uniform. "Seguridad Privada" must be written along the left chest area of the uniform. Pants must be black with a five-centimeter white stripe on each side. Similarly, hats and footwear must be black, the former including "Servicio de Seguridad Privada" written across their front. Coats must be gray. The words policia, agentes, and investigadores are prohibited from being written anywhere on the uniform. Vehicles must be white and state "seguridad privada" below the company logo on the side of each back door (Jalisco State Government, 2014). 
Except for Mexico City, all regulations describe the proper conduct to be followed by private security employees when interacting with citizens. Both the federal government and the Jaliscan government emphasize human rights standards in their regulations. Federal regulations state that personnel must respect human rights as delineated in the Mexican Constitution and international treaties, by treating people correctly, impartially, and with dignity and integrity and abstaining from all arbitrary and unjustified violence, including abuse and torture. In turn, Jalisco's regulations state that private security employees must respect human rights in the same manner as the rules accorded to the state public security forces (Jalisco State Government, 2014). In Nuevo León, private security personnel are expected to show professionalism, honesty, and respect for other people's rights, as well as to avoid abuse and arbitrary violence and follow the principles of conduct expected of public security employees as established in the Public Security Law of Nuevo León (Nuevo León, 2021). Despite mentioning the avoidance of abusive behavior and arbitrary violence, none of the regulations include detailed guidelines regarding the use of force.

All the regulations provide guidelines regarding cooperation between private security firms and police departments. The federal government, Mexico City, Jalisco, and Nuevo Leon stipulate that private security serves an auxiliary and complementary service to public security, requiring it to share data with the police and assist on criminal investigations (México, 2011; México, 2014; Jalisco, 2014; Nuevo León, 2021). Nuevo León and Jalisco mandate private security to assist the police "when it is required", so that coordination is even more generalized (Jalisco State Government, 2014; Nuevo León, 2017). 
Table 4

Entrance Requirements for Firms to Enter Industry Applied to Mexican Cases

\begin{tabular}{|c|c|c|c|c|}
\hline \multicolumn{5}{|c|}{ Entrance Requirements for Firms to Enter Industry } \\
\hline & $\begin{array}{c}\text { Federal } \\
\text { Government }\end{array}$ & $\begin{array}{l}\text { Mexico } \\
\text { City }\end{array}$ & Jalisco & Nuevo León \\
\hline Payment of Fee for License & $x$ & $x$ & $x$ & $x$ \\
\hline $\begin{array}{l}\text { Restrictions on Background } \\
\text { of Owner/Qualifying Agent }\end{array}$ & Partial & Partial & Partial & Partial \\
\hline $\begin{array}{l}\text { Minimum experience/ } \\
\text { Qualifications of Owner/ } \\
\text { Qualifying Agent }\end{array}$ & Partial & Partial & Partial & Partial \\
\hline $\begin{array}{l}\text { Minimum Training for } \\
\text { Owner/Qualifying Agent }\end{array}$ & $x$ & & & \\
\hline $\begin{array}{l}\text { Passing of Examination of } \\
\text { Owner/Qualifying Agent }\end{array}$ & & & & \\
\hline $\begin{array}{l}\text { Fingerprinting of Licensing } \\
\text { Agent }\end{array}$ & $x$ & $x$ & $x$ & $x$ \\
\hline \multicolumn{5}{|c|}{ Examination Requirements for Individuals to Work in Industry } \\
\hline \multicolumn{5}{|l|}{$\begin{array}{l}\text { Payment of Fee for } \\
\text { License/Registration }\end{array}$} \\
\hline $\begin{array}{l}\text { Restrictions on Background } \\
\text { of Employees }\end{array}$ & $x$ & $x$ & $x$ & $x$ \\
\hline $\begin{array}{l}\text { Minimum Training for } \\
\text { Employees }\end{array}$ & $x$ & $x$ & $x$ & $x$ \\
\hline \multicolumn{5}{|l|}{ First Aid Certification } \\
\hline $\begin{array}{l}\text { Passing of Examination } \\
\text { by Employees }\end{array}$ & $x$ & $x$ & $x$ & $x$ \\
\hline Drug and Alcohol Testing & Partial & Partial & Partial & Partial \\
\hline \multicolumn{5}{|l|}{$\begin{array}{l}\text { Requirement or Refresher/ } \\
\text { Specialist Training }\end{array}$} \\
\hline \multicolumn{5}{|c|}{ Minimum Standards of Operation } \\
\hline Bonding/Insurance & & $x$ & $x$ & \\
\hline Facilities/Equipment & $x$ & $x$ & $x$ & $x$ \\
\hline Other Standards & $x$ & $x$ & $x$ & $x$ \\
\hline Code of Conduct & $x$ & & Partial & $x$ \\
\hline Use of Force Guidelines & Partial & $x$ & $x$ & Partial \\
\hline Police Cooperation & $x$ & $X$ & $x$ & $x$ \\
\hline
\end{tabular}




\section{Summary of Findings and Brief Comparisons with Other Cases}

Despite some variation, the regulations formulated by the Federal government of Mexico, Mexico City, Nuevo León, and Jalisco tend to be quite stringent and robust, entailing fees for private security licenses, copious amounts of documentation for registration, and strict uniform, vehicle, and equipment requirements. Apart from Jalisco, all the regulations address a wide number of private security sectors. Although documents lack precise requirements for firms to enter the industry and vary as to hiring requirements, all the regulations include standards for new hires and for the administration of several tests either before hiring or to continue employment. Training standards also vary, but they all provide detailed requirements or force companies to send their employees to police academies. All the cases also stipulate coordination with law enforcement, and only Mexico City lacks a code of conduct.

In comparison, these regulations tend to be wider and more comprehensive than most U.S. states and a number of foreign countries (Button, 2007; Button, 2012; Button and George, 2006; McCrie, 2017; Waard, 1999). In a study conducted by McCrie (2017), the author demonstrates the massive deficiencies and gaps in state private security regulations in the United States of America, verifying, for example, that twelve states lack any regulations for unarmed guards, while thirteen have none for armed guards. Moreover, just over half of states require background checks as part of the hiring process, and multiple states require no basic training or firearms training for guards. In Slovakia, private security companies do not need a license to operate and uniforms for guards are optional. In Austria and the Czech Republic, the industry falls within the country's general commercial 
law, thus there are no specific private security regulations (CoESS, 2013).

Nevertheless, the consequence of imposing tight regulations has had the opposite effect that regulators intended: instead of promoting increased state control over the private security industry, private security providers have distanced themselves from the state by avoiding registration and regulatory measures. As the Director General of the federal private security office of Mexico explained, "it's easier not to comply than to comply" with private security laws (Arámbula, 2014). Moreover, weak enforcement has allowed security providers to avoid the law while corrupt government officials use their power as gatekeepers to make access to private security and weapons licenses easy for some and extremely difficult for others. Consequently, informality in the industry is widespread as will be described in the following section.

\section{Widespread informality}

Private security firms operating on the margins of the law by failing to register or only partially registering are colloquially known as patitos. Patitos tend to be small, local firms that appear for a few months with one name, disappear, and then re-emerge with a new name. The highly variable quality of private security firms served as a major impetus to develop private security laws. After the establishment of these laws, patitos quickly emerged, spurring reforms to create more stringent regulations to eliminate these unregulated and underregulated firms. Nevertheless, I argue that the imposition of even stricter and more costly regulations, combined with weak enforcement and corruption, have further fueled the spread of patitos throughout Mexico. Private security representatives, government officials, journalists, academics, and members of civil society all tend to agree that 
widespread informality in the private security sector is one of the most serious - if not the most serious problem affecting the industry.

The number of unregistered private security firms in Mexico fluctuates widely due to a lack of solid documentation, with some reports placing the number at forty to sixty percent, while other estimates go as high as eighty or ninety percent (Domínguez, 2013; Frutos, 2014; Universal, 2014). A study conducted in 2013 by the Consejo Nacional de Seguridad Privada found that only 659 out of the 8,500 private security companies in Mexico were registered with the government (Milenio, 2013). Around 60\% of firms in Jalisco are estimated to be unregulated, while $25-30 \%$ of the companies in Nuevo León are unauthorized (Abundan empresas..., 2015; Ibarra, 2014; Osorio, 2016). ${ }^{2}$ Despite the lack of data on the specific percentage of unregistered companies in Mexico City, complaints of widespread informality are common in the capital.

\section{High costs of obeying regulations}

Besides registering in each state where they are active, private security firms operating in more than one state must also register with the federal government. Moreover, some municipal governments also mandate that companies register with them. Paying registration fees with the state, municipal, and federal governments can be exceedingly costly for companies, thus serving as a major deterrent to registration. The following table shows the costs involved with registering and maintaining a private security company in each jurisdiction.

\footnotetext{
2 One estimate places the unregistered rate in Nuevo León as high as eighty percent (La Seguridad..., 2010).
} 
Table 5

Private Security Licensing Fees (Mexican pesos)

\begin{tabular}{|c|c|c|c|c|}
\hline & Federal & Mexico City & Jalisco & Nuevo Leon \\
\hline $\begin{array}{l}\text { Private security } \\
\text { permit (fee varies } \\
\text { depending } \\
\text { on service) }\end{array}$ & $\begin{array}{c}\$ 18,353- \\
\$ 19,808(\sim 885 \\
-\$ 956 \text { USD) }\end{array}$ & $\begin{array}{c}\$ 13,723- \\
\$ 18054(\sim 662 \\
-\$ 871 \text { USD) }\end{array}$ & $\begin{array}{c}\$ 18,500 \\
\text { (flat rate) } \\
(\sim 1,032 \\
\text { USD) }\end{array}$ & $\begin{array}{l}\$ 15,448- \\
\$ 16,328 \\
(\sim \$ 865- \\
\$ 915 \text { USD })\end{array}$ \\
\hline $\begin{array}{l}\text { Authorization for } \\
\text { individuals and } \\
\text { companies to } \\
\text { perform private } \\
\text { security activities }\end{array}$ & $\begin{array}{c}\$ 5,943 \\
(\sim 287 \text { USD) }\end{array}$ & $\begin{array}{c}\$ 5,149 \\
(\sim 248 \text { USD })\end{array}$ & & $\begin{array}{c}\$ 6,030 \\
(\$ 340 \text { USD) } \\
\$ 4,962 \text { per } \\
\text { year for } \\
\text { revalidation } \\
\text { (\$280 USD) }\end{array}$ \\
\hline $\begin{array}{l}\text { Issuance of } \\
\text { documents and } \\
\text { information } \\
\text { from the private } \\
\text { security registry }\end{array}$ & & $\begin{array}{c}\$ 329 \\
(\sim 16 \text { USD) }\end{array}$ & & \\
\hline $\begin{array}{l}\text { Documents } \\
\text { certification }\end{array}$ & $\begin{array}{c}\$ 22 \\
(\sim 1 \text { USD) }\end{array}$ & $\begin{array}{c}\$ 13.50(\text { per } \\
\text { page) }(\sim 00.65 \\
\text { USD) }\end{array}$ & & \\
\hline $\begin{array}{l}\text { Personnel } \\
\text { registration }\end{array}$ & $\begin{array}{c}\$ 199 \\
\text { ( } \$ 10 \text { USD) }\end{array}$ & $\begin{array}{c}\$ 215(\text { per } \\
\text { person) }(\sim \$ 10 \\
\text { USD) }\end{array}$ & & $\begin{array}{c}\$ 160 \\
\text { (\$9 USD) }\end{array}$ \\
\hline $\begin{array}{l}\text { Canine } \\
\text { registration }\end{array}$ & & $\begin{array}{l}\text { \$132 per canine } \\
\quad(\sim 6 \text { USD })\end{array}$ & & $\begin{array}{l}\$ 80 \text { per } \\
\text { canine } \\
\text { ( \$4 USD) }\end{array}$ \\
\hline $\begin{array}{l}\text { Vehicle and radio } \\
\text { communication } \\
\text { registration }\end{array}$ & $\begin{array}{c}\$ 60 \\
(\sim 3 \text { USD })\end{array}$ & $\begin{array}{c}\$ 332 \text { per item } \\
\text { ( \$16 USD) }\end{array}$ & & $\begin{array}{l}\$ 80 \text { per } \\
\text { vehicle } \\
\text { ( \$4 USD) }\end{array}$ \\
\hline $\begin{array}{l}\text { Equipment } \\
\text { registration }\end{array}$ & $\begin{array}{c}\$ 60 \\
(\sim 3 \cup S D)\end{array}$ & $\begin{array}{l}\$ 12 \text { per item } \\
(\sim 00.58 \text { USD })\end{array}$ & & $\begin{array}{c}\$ 80 \text { per } \\
\text { bulletproof } \\
\text { vest } \\
(\sim 4 \text { USD })\end{array}$ \\
\hline $\begin{array}{l}\text { Firearms } \\
\text { registration }\end{array}$ & $\begin{array}{c}\$ 60 \\
(\sim 3 \text { USD })\end{array}$ & $\begin{array}{l}\$ 332 \text { per } \\
\text { firearm } \\
(\sim 16 \text { USD) }\end{array}$ & & $\begin{array}{l}\$ 80 \text { per } \\
\text { firearm } \\
\text { ( \$4 USD) }\end{array}$ \\
\hline
\end{tabular}

Sources: Dirección General de Seguridad Privada y Colaboración Interinstitucional de la Secretaría de Seguridad Ciudadana de la Ciudad de México; Direccíon de Seguridad Privada de la Comisión Nacional de Seguridad; State Employee, 2014; Ibarra, 2014. 
Private security providers openly complain about the high costs associated with registering and maintaining a company and the copious amounts of paperwork involved in the process. Due to these elevated costs, many companies register after they have existed for a few years and earned enough income to afford to pay registration fees and compete with other registered companies (Security Company Manager, 2014). Moreover, most companies that do register tend to only do so with individual states and not with the federal government, either because they only operate in one state or because they want to avoid the registration fees, additional paperwork, and regulations linked to the federal law. Consequently, only $20 \%$ of registered companies are regulated by the federal government (Desfassiaux, 2011, p. 88). As one security consultant explained, "it's an expensive proposition for them [private security firms] and if they can get away without it then they do it" (Security Consultant [1], 2013).

Hiring and maintaining personnel can also be very costly and time consuming for private security companies. According to the Director General of the federal government private security office, a company with 1,000 employees must submit thousands upon thousands of training reports to the government (Arámbula, 2014). Moreover, requesting background checks and administering each test - medical, psychological, toxicological - can be quite expensive for the companies, adding up to about $\$ 5,000$ to $\$ 10,000$ pesos per employee or applicant (Retired Government Functionary, 2014).

Employee turnover rates are extremely high in the field of private security, and firms often provide short-term contracts that may last only a few weeks or months. Consequently, companies are even more reluctant to spend hiring and training costs on them (Perret 2013, p. 168). Some companies will attempt to reduce costs by withholding information during the registration process or by registering only part of their personnel. A company with one hundred 
employees, for example, may only report fifty of them, thus paying the hiring and registration fees of half of their personnel and avoiding major costs. Avoiding detection of this discrepancy is not difficult because verifiers are mostly interested in looking at paperwork and documentation instead of observing actual operations (Retired Government Functionary, 2014).

Proper training also incurs an elevated cost, so that many companies, especially small ones, often bypass or curtail this process. In many cases, guards receive a basic oneto two-hour lesson and are sent into the field (Bagur, 2014; Security Consultant [2], 2014). To avoid training expenses, unregulated private security companies often hire former military and police officers dishonorably discharged for corruption or incompetence, since they already have prior experience in the field (Security Company Manager, 2014; Alvarado, 2012).

Acquiring a firearms license is costly and difficult, which dissuades companies from legally obtaining them. All firearms licenses are granted by SEDENA and all firearms purchases must be made through the institution. The application process for a license involves significant amounts of paperwork, time, and money (Security Company Owner [2], 2014). The license cost for private security companies is $\$ \$ 40,503.00$ pesos $(\sim 1,957$ USD) - more than double the cost of a license to operate a private security firm in most states - and, once granted, the company must revalidate the license annually for the same cost as the initial registration fee listed (SEDENA, 2021). These companies are also required to rent or construct a shooting range and provide weapons training certification to all of their employees, both costly endeavors (Security Company Manager, 2013).

Beyond legal requirements, private security providers have highlighted the importance of political connections for obtaining a firearms license, thus providing evidence of the 
tollbooth model in action. (Security Consultant [2], 2014). As stated by a private security representative, although members of militias, former police officers, military officers, commanders, and politicians acquire firearm licenses with ease, such a doing is extremely difficult for everybody else (Security Manager [4], 2014). By establishing these barriers to access, government officials can use their power to benefit those with whom they have personal and prior professional relationships while ignoring the rest. The thriving underground economy around weapons licenses is yet another factor for obtaining a license, whereby individuals connected to those within SEDENA acquire and illegally sell licenses off for a profit. According to one of these sellers, "winning the lottery is easier than obtaining a license" (Gutierrez, 2013, translated from Spanish. As a result, the high barriers to acquiring a weapons license seemingly indicates that the state is effectively controlling the security industry in this realm, however, the process for obtaining a license is arbitrary and does not follow the stated intentions of the regulations put into place. Moreover, the creation of high and arbitrary barriers also serves to incentivize private security providers to avoid the process altogether by purchasing weapons licenses or firearms themselves on the black market.

\section{Corruption}

Upper and lower-level government corruption plagues state - private security relations. By creating strict and costly regulations, politicians, government officials, and bureaucrats working in private security law enforcement agencies have enhanced opportunities to use their authority as gatekeepers to provide preferential treatment and unequal benefits to associates while extracting bribes and complicating the registration process for others. These cases evince the capture theory "tollbooth" variant. As Davis (2003) explains, "formal laws do little to regulate private police in a 
country where regulators - i.e. the public police - themselves are corrupt. If the keepers are themselves transgressors, what value is the law, even with a formal democracy on the books?" Corruption in registration, inspection, and enforcement has further limited the power and effectiveness of private security regulations to allow the state to control and direct the industry in a manner beneficial to state capacity as it creates inequality in the registration process, further discourages companies from abiding by regulations, and creates resentment from firm owners.

At the upper levels of the federal and state governments, there is something of a revolving door between public security departments and the private security industry. Those who retire from the armed forces and public security will most likely enter private security. A retired captain who later founded his own security company described a common joke between retired military officers that goes: "Now that you've retired, what company are you going to run?" (Retired Private Security Owner, 2014). Private security enforcement agencies are also populated with former members of the police and the military, thus facilitating collusive relationships. For example, Raúl Rojas Mendoza was appointed Director of the Dirección de Seguridad Privada y Procedimientos Sistemáticos of Mexico City only after serving a long career in the Mexican Armed Forces (Rojas Mendoza, 2014). Former officials from the State Department, intelligence, military, and public security use their government connections to establish security companies more easily, obtain weapons licenses, avoid or receive rubber-stamped private security registration, and acquire public and private contracts.

For example, Eider Martín Silva Arboleda established a private security company while working at the Secretaría de Seguridad Pública de Jalisco under the supervision of Attorney General Luis Carlo Nájera. After Arboleda left the public sector, Nájera granted his company a contract worth close 
to $\$ 15$ million pesos $(\sim \$ 863,000$ USD) to provide specialized training to the preventive police of Jalisco (Plascencia, 2014). Similarly, soon after leaving his post as Secretario de Seguridad Pública (Mexico's top police chief), Genaro García Luna established himself within a private security company whose owner he had connections with while in public office, bringing a group of people with whom he had worked with in the secretariat along him - including former members of the U.S. Federal Bureau of Investigations, Drug Enforcement Agency, Central Intelligence Agency, and the Colombian National Police force (Ramírez, 2014). Additionally, private security company owners accused Francisco Cienfuegos, a Nuevo León deputy and spokesmen for Governor Rodrigo Medina de la Cruz, of using his authority to delay other companies from receiving their private security licenses so that he could garner more security contracts for his own company, Protege - a private security company he owned with his sister (Frutos, 2014).

Private security company owners have also used their power and connections to gain public office and manipulate government policy for their own benefit. In 2010, Servando Sepúlveda - the owner of Centurión Alta Seguridad Privada, one of the largest private security providers in Guadalajara - was appointed the Director de Seguridad Pública of the city. Once in office, Sepúlveda proposed and advocated for policy changes benefitting the private security industry, such as requiring all banks to use the services of private security companies for their protection needs (La Seguridad..., 2010; Reza, 2010).

These cases provide clear evidence of the means through which relationships between government officials and private actors involved with the security sector lead to acts of collusion. In an attempt to reward themselves, their former colleagues, or their friends by providing them with security contracts or weapons and private security licenses, 
public officials are violating the rules and norms of their office and consequently creating resentment in the industry. Private security providers have complained that those with special government connections possess an unfair competitive advantage (Frutos, 2014; Security Company Manager [2], 2014), thus harming their interests because other actors are receiving benefits to which they are not legitimately entitled (Philp 2008, p. 310). As a result, further distrust of the government is sowed within the private security industry and incentives to engage in the registration process are reduced. Additionally, executives from smaller firms that lack government connections complain that they have been barred access to security licenses, which left them with no choice but to operate as patitos (Frutos, 2014).

Strict and costly regulations, unequal treatment towards private security providers, and lax enforcement encourages informality in an environment where it is 54 already the norm. Despite the difficulty in identifying the percentage of unregulated firms due to the hidden nature of informality, $60 \%$ of Mexican workers are estimated to operate in the informal economy (Hughes, 2013). In the private security industry, these estimates reach as high as $80-90 \%$, surpassing the national average of general participation in the informal economy (Universal 2014).

Bribery is yet another major problem in Mexico, being commonly expected and widely accepted in the registration process. According to Bailey (2014), a high prevalence of informality promotes a culture of illegality and reinforces "expectations for extra-legal exchanges throughout society” (p. 32). Transparency International's 2017 Global Corruption Monitor report found $51 \%$ of Mexicans admitted to paying bribes. This percentage is the highest in all of Latin America. Bribery is, therefore, commonly expected and accepted in the registration process. Verifiers regularly demand bribes from company owners during inspection 
visits, which smaller firms may try to avoid by entering the informal market instead. Security firm owners will also take the initiative by offering bribes to verifiers in order to receive rubber stamped registration or inspection certification (Muller 2010, p. 141; Arámbula, 2013). Although problematic in any sector, corruption and evasion are particularly dangerous in the security sector, considering the ability of private security providers to wield violence and the state's primary responsibility to provide security to its citizenry and maintain law and order.

\section{Weak enforcement}

Corruption and the high costs associated with strict regulations help discourage security providers from registering and abiding by the law - issues further aggravated by the state's inability to effectively enforce it. As Perret (2013) explains, "Although Mexican laws such as the Federal Law on Private Security contemplate and seek to address several of the challenges posed by the privatization of security in Mexico, such regulations are only adequate on paper. In real life, implementation of the laws falls short, resulting in deficient regulation of private security" (p. 169). The government's inability to identify, sanction, and compel this large swath of unregulated firms to register and obey the law isevidence of the state's failure to enforce its private security regulations.

Weak enforcement is linked to a lack of political will and pressure to designate more energy and resources to strengthening government oversight of private security companies (Muller, 2010, p. 142). Mexico City, Jalisco, and Nuevo León all face shortages in personnel that make authorizing and inspecting all the companies in their domains quite difficult, if not impossible. In many cases, site visits to company headquarters are rare (Security Company Manager 2014). Therefore, regulated companies often lack supervision and 
can easily subvert the law. In Mexico City, the Dirección de Seguridad Privada has only four official verifiers authorized to validate the registration of private security companies and oversee their operations to ensure they are complying with regulations (Rojas Mendoza, 2014). Considering the hundreds of private security companies operating and attempting to register in the capital, having so few verifiers makes the oversight process very difficult. The Director General de Seguridad Privada y Procedimientos Sistemáticos de Operación del Distrito Federal, Raúl Rojas Mendoza, argues that the office needs more verifiers to successfully perform the tasks demanded of the Dirección de Seguridad Privada (2014). Oversight that does occur of registered companies is, therefore, quite minimal. It generally amounts to the Dirección de Seguridad Privada making sure a company's registration papers are all accounted for and then checking in once a year to demand its annual fees. Even Rojas Mendoza admitted that, despite their efforts, his office is unable to inspect every company operating in the city each year (2014).

In Jalisco, the Consejo Estatal de Seguridad Pública sets a goal to inspect twenty-five percent of registered companies per year (State Employee 2014). According to a staffer at the Consejo's Area de Seguridad Privada, his low bar was established due to a lack of manpower to inspect every company in the state. Despite their goal, a recent report by the Robert Strauss Center (2018) found that the Consejo only inspects an average of three percent of the companies operating in the state each year (p. 5). Only four employees work in the Area de Seguridad Privada and three of them are qualified to do inspections. The staffer noted that it is quite difficult to create new openings in the area and therefore doubts any new verifiers will be hired soon (State Employee, 2014). Inspecting a maximum of $25 \%$ of companies per year is clearly unacceptable and, therefore , 
exhibits the Consejo's clear inability to properly enforce the state's private security regulations.

An administrator at the Dirección de Control y Supervisión a Empresas y Servicios de Seguridad Privada in Nuevo León described how the office only has two verifiers along with a legal representative who is also sent out to do inspections since they are so understaffed. She explained that the office needs at least five verifiers to effectively perform all inspections in the state (Ibarra, 2014).

Public office holders have received minimal public pressure to reign in the private security industry, thus limiting their incentives to expend more resources on private regulations enforcement. Despite the major efforts taken by civil society to critique, protest, and improve public security forces in Mexico, little public attention has been directed at the private security industry. Major Mexican news publications often publish a few stories each year lamenting the high levels of informality in the industry, but they do not seem to have much effect amongst the public. Although large demonstrations have taken place throughout the country over the past three decades to protest increases in crime and the failures of Mexico's police forces and criminal justice system, none have addressed improvingthe private security industry. Civil society organizations, such as Mexicanos Contra la Delincuencia and Causa en Común and think tanks, such as El Instituto para la Seguridad y Democracia and El Instituto Ciudadano de Estudios sobre la Inseguridad, have formed out of these protests with the primary goal of understanding how to improve the criminal justice system in Mexico and reduce incidences of crime and violence. Yet none of these groups pay much (if any) attention to private security. Such a lack of pressure translates into a lack of incentive for office holders to take additional actions regarding the industry. AsMuller (2010) points out, "due to the lack of both public 
and academic debates on private security, the topic of private security does not rank high on the security agenda of local politicians, as engaging in issues of private policing offers little political gains" (p. 142).

Beyond the lack of public pressure, politicians may resist the enforcement of strict regulations due to political calculations. The private security sector is a major employer in Mexico with low entry barriers. Jobs in the security field, such as guard services, require little to no experience nor education, thereforeprivate security company headquarters are often located in lower-income neighborhoods for recruitment purposes (Security Company Owner [1], 2014). Consequently, it is in the interest of politicians to ensure their constituents continue to have access to these employment opportunities. Muller (2016) describes the predicament of a local politician in Mexico City who, despite believing in stringent private security regulations, opposes its enforcement because many of her poorer constituents rely on the private security sector as a source of employment. Thus, the stricter enforcement of private security regulations would disqualify a number of her constituents from working in the sector, which could lead to negative electoral repercussions (p. 135).

As a result of weak enforcement, firms can benefit financially by avoiding regulations and undercutting the market in an environment where informal exchanges are more readily acceptable. Unregistered companies can charge much lower prices for their services because they do not pay taxes and registration fees and avoid laws regulating training requirements, uniforms, hiring standards, and wages. Thus, these companies often pay lower wages than those established by the law and provide their employees with shoddy uniforms and equipment. As a result, registered private security companies 
charge clients an average of $\$ 13,000$ to $\$ 14,000$ pesos $(\sim 700$ - \$740 USD) per month, whereas unregistered companies may charge as little as $\$ 6,000$ pesos ( \$325 USD) (Pallares Gómez, 2014).

\section{Conclusion}

Despite the traditional view that comprehensive regulations improve government control over private security actors, the Mexican case displays the opposite effect: strict and expensive regulations have helped reduce the state ability to effectively control and monitor the private industry and dissuaded private security owners from participating in the formal market. Government bureaucrats and officials have used the rigidity of private security laws to their advantage, adopting the "tollbooth approach" to provide their associates and those willing to pay bribes with easier access to private security permits while barring access to others. Weak enforcement of the law has enabled the avoidance of the government's reach, which has to do with a lack of strong political incentives to devote additional resources to private security enforcement agencies. In sum, high entry barriers, weak enforcement, and rampant corruption, have led most firms to avoid or only partially register, or engage in corrupt activities to gain access to the security market, leading to widespread informality that has severely limited government control over the industry.

The Mexican government should take a number of steps to improve this situation. Unlike some public choice theorists, I am not arguing to eliminate most or all regulations in favor of letting the free market take over. In many ways, much of the Mexican private security market is already guided by the free market - since a large percentage of firms operate outside of the government's reach. As evidenced, firms operating in this environment often contribute to the problem of insecurity through their tendency to hire unqualified individuals, 
potential criminals, and dishonorably discharged members of the police and military, provide little to no training to employees, and low wages. Prenzler and Sarre (2008) describe the deficiencies of relying on criminal law, civil law, market forces, or self-regulation for controlling the industry (p. 269-270). Moreover, Zedner (2006) highlights that private security regulations serve a number of important functions.Most notably, security is of a higher and more sensitive order than most commodities and, therefore, "the level of risk to which the public are exposed by ill-qualified staff, inadequate training or inadequate (or no) insurance cover is deemed so grave as to justify, even demand, state intervention" (p. 276).

Therefore, instead of eliminating regulatory frameworks in Mexico, private security regulations should be simplified and standardized across the country. Private security companies should be subject to one standard national law as opposed to a different one in each state where they ope60 rate. Subjecting all private security providers to one national private security law would reduce confusion amongst providers, standardize registration costs, and create a consistent standard for firms to follow throughout the country. Limiting requirements to acquiring state-specific permits and additional fees would also reduce the number of access points for "tollbooth activity" that promotes corrupt activity. Mexican private security companies have lobbied the federal government to pass a standardized national security law, however, the bill has languished in the Mexican legislature for years .Unfortunately, the hurdles to passing this law are immense as a standardized national law would eliminate individual states' access to registration fees and reduce their power over local private security providers.

Second, the enforcement of regulations must be significantly strengthened by hiring, training, and certifying more verifiers to expand government coverage and ensure that all firms are properly following the law specifications. Third, 
the government must identify and reach out to firms avoiding regulations to explain the regulatory process and demand that they register with the government. Firms that continue avoiding registration should be shutdown with fines assessed to the owners. Combining a simplified, standardized law that covers all firms with a larger and enhanced regulatory enforcement apparatus would go a long way toward improving Mexico's private security crisis. Unfortunately, deeply entrenched corruption at the municipal, state, and federal levels and a lack of strong public pressure and political incentives to alter the status quo, make the implementation of the suggested policy improvements unlikely.

This study shows the connections between strong private security regulations and weak compliance in certain instances. Without strong state institutions able to properly enforce the law, tamp down on corruption, and discourage informality, strict and comprehensive private security regulations can backfire and reduce state control over the industry, thus reinforcing its own weakness. Therefore, simply assessing the strengths and weaknesses of a state's regulatory regime is obviously not sufficient to understanding its effectiveness. Likewise, describing low compliance and weak enforcement without highlighting potential links between these outcomes and regulations rigidity is also unsatisfactory. With this study, I hope to stimulate more research in the Global South where these instances are more common that bridges this gap and questions commonly held misperceptions about private security regulations and the causes for their ineffectiveness.

\section{Logan Puck}

Visiting Assistant Professor of Politics at Bates College. Lewiston, Maine, EUA. 


\section{Bibliography}

ABRAHAMSEN, Rita; WILLIAMS, Michael. 2011. Security beyond the state:

Private security in international politics. New York: Cambridge University Press. DOI: 10.1017/CBO9780511974441

ABUNDAN EMPRESAS de seguridad "patito". 2015. ABC Notícias, Monterrey, 4 aug. Disponível em: https:/ / bit.ly/32opdi1. Acesso em 27 dez. 2021.

ALVARADO, Arturo. 2012. El tamaño del infierno: Un estudio sobre la criminalidad en la Zona Metropolitana de la Ciudad de México. Mexico City: El Colegio de México.

ARÁMBULA, Juan Antonio. 2014. Director General de Seguridad Privada, Comisión Nacional de Seguridad, Secretaría de Gobernación.

Mexico City, January 17.

ARGUETA, Otto. 2013. Private security in Guatemala: Pathway to its proliferation.

Baden-Baden: Nomos. DOI: 10.5771/9783845245133

BAGUR, Afonso Ramón. 2014. Commissioner, Servicio de Protección Federal. Mexico City, January 24.

BAILEY, John. 2014. The Politics of Crime in Mexico: Democratic Governance in a Security Trap. Boulder: First Forum Press.

BORN, Hans; BUZATU, Anne-Marie. 2008. New dog, old trick:

An overview of the contemporary regulation of private security and military contractors. Security and Peace. Baden-Baden, v. 26, n. 4, pp. 185-190. DOI: 10.5771/0175-274x-2008-4-185

BUTTON, Mark. 2007. Assessing the Regulation of Private Security across Europe. European Journal of Criminology. Thousand Oaks, v. 4, n. 1, pp. 109-128. DOI: 10.1177/1477370807071733

BUTTON, Mark. 2012. Optimizing security through effective regulation:

Lessons from around the globe. In: PRENZLER, Tim. (ed.).

Policing and security in practice: Challenges and achievements. London:

Palgrave MacMillan. pp. 204-220.

BUTTON, Mark; GEORGE, Bruce. 2006. Regulation of Private Security:

Models for Analysis. In: GILL, Martin. (ed.). The handbook of security.

New York: Palgrave MacMillan. pp. 563-585.

CIUDAD DE MÉXICO. 2021. Secretaría de Seguridad Ciudadana.

Dirección General de Seguridad Privada y Colaboración

Interinstitucional. Pagos en la Tesorería de la Ciudad de México.

Disponível em: https:/ /bit.ly/3JqixR6. Accesso em: 27 dez. 2021.

CoESS. 2013. Private security services in Europe: CoESS Facts and

Figures 2013. Brussels: Coess.

CoESS. 2015. Private security services in Europe: CoESS Facts and

Figures 2015. Brussels: Coess. 
DAVIS, Diane E. 2007. Law Enforcement in Mexico: Not Yet Under Control. Nacla. Washington, 25 de setembro. Disponível em: https://bit.ly/3qhe1f0. Acesso em: 22/12/2021.

DE SOTO, Hernando. 1989. The other path: The invisible revolution in the Third World. New York: Harper \& Row.

DESFASSIAUX, Alejandro. 2011. Tu seguridad: Mitos y realidades de la seguridad privada. Morelos: Grupo Mundo Ejecutivo.

DJANKOV, Simeon; LA PORTA, Rafael; LOPEZ-DE-SILAMES, Florencio; SHLEIFER, Andrei. 2002. The regulation of entry. The Quarterly Journal of Economics. Oxford, v. 117, n. 1, pp. 1-37. DOI: 10.1162/003355302753399436

DOMINGUEZ, Pedro. 2013. "Patito", nueve de cada 10 empresas de seguridad privada. Milenio, Cidade do México, 12 jul. Disponível em: https://bit.ly/3pkGOjB. Acesso em: 22 dez. 2021.

DOMÍNGUEZ, Pedro. 2013. Ilegales, 9 de cada 10 empresas de seguridad en México. Milenio, Cidade do México, 12 mai.

Disponível em: https://bit.ly/33LaiP3. Acesso em: 22 dez. 2021. ETZIONI, Amitai. 2009. The capture theory of regulations - revisited.

Society. New York, v. 46, pp. 319-323. DOI: 10.1007/s12115-009-9228-3

FARBER, Daniel; Frickey, Philip. 1991. Law and Public Choice: A Critical

Introduction. Chicago: The University of Chicago Press.

FRUTOS, Melva. 2014. Seguridad privada es 60 percent "patito".

Reporte Indigo, Cidade do México, 28 nov. Disponível em:

https://bit.ly/3JbRf0M. Acesso em: 22 dez. 2021.

GLAESER, Edward; SHLEIFER, Andrei. 2003. The rise of the regulatory state. Journal of Economic Literature. Nashville, v. 41, n. 2, pp. 401-425. DOI: 10.1257/002205103765762725

HANTKE-DOMAS, Michael. 2003. The public interest theory of regulation: Non-Existence or misinterpretation? European Journal of Law and Economics. New York, v. 15, n. 2, pp. 165-194. DOI: 10.1023/A:1021814416688

HEMMENS, Craig; MAAHS, Jeff; SCARBOROUGH, Kathryn; COLLINS, Pamela. 2001. Watching the Watchmen: State Regulation of Private Security 1982-1988. Security Journal. New York, v. 14, n. 4, pp. 17-28. DOI: $10.1057 /$ palgrave.sj.8340095

HUGGINS, Martha. 2000. Urban violence and police privatization in Brazil: Blended invisibility. Social Justice. Ann Arbor, v. 27, n. 2, pp. 113-134. Disponível em: https://bit.ly/3qjUWsv. Acesso em: 22 dez. 2021. 
HUGHES, Krista. 2013. Mexico Aims to Bring Shadow Economy into the Light. Reuters, Londres, 26 jun. Disponível em: https://reut.rs/3yR4K0O. Acesso em: 22 dez. 2021.

IBARRA, Karla. 2014. Administrator, Dirección de Control y Supervisión a Empresas y Servicios de Seguridad Privada. Monterrey, November 24.

JALISCO. 2004. Reglamento de los Servicios Privados de Seguridad del Estado de Jalisco. Guadalajara, 29 jun. Disponível em: https://bit.ly/3JcpHZ2. Acesso em: 22 dez. 2021.

LA SEGURIDAD privada, negocio rentable fuera de norma oficial. 2010. Informador, Guadalajara, 23 mai. Disponível em: https://bit.ly/3yQQYve. Acesso em: 22 dez. 2021.

LELOUP, Pieter; WHITE, Adam. 2021. Questioning Anglocentrism in plural policing studies: Private security regulation in Belgium and the United Kingdom. European Journal of Criminology, Thousand Oaks, pp. 1-20. DOI: 10.1177/14773708211014853

LOPES, Cleber. 2018. Plural Policing and Public Opinion in Brazil. Security Journal, New York, v. 31, n. 2, pp. 451-469. DOI: 10.1057/ s41284-017-0110-5

LOPES, Cleber; MORAES, Caio de. 2019. Statutory regulation of the security industry under pressure: The Brazilian case. International Journal of Comparative and Applied Criminal Justice, Abingdon, v. 45, n. 2, pp. 189-205. DOI: $10.1080 / 01924036.2019 .1695641$

MCCHESNEY, Fred. 1987. Rent extraction and rent creation in the economic theory of regulation. Journal of Legal Studies. Chicago, v. 16, n. 1 , pp. 101-118. DOI: $10.1086 / 467825$

MCCRIE, Robert. 2017. Private Security Services Regulations in the United States Today. International Journal of Comparative and Applied Criminal Justice. Ann Arbor, v. 41, n. 4, pp. 287-304. DOI: $10.1080 / 01924036.2017 .1364281$

MÉXICO. 1948. El Reglamento para los investigadores, detectives y policías o pertenecientes a organismos de servicio público descentralizado o concesionado. Diario Oficial de la Federacion. Cidade do México, 13 out. Disponível em: https://bit.ly/3eePtxF. Acesso em: 22 dez. 2021. MÉXICO. 1985. Decreto por el que se abroga el reglamento de los investigadores, detectives y policías privadas o pertenecientes a organismos de servicio público descentralizado o concesionado, de fecha 22 de septiembre de 1948, publicado el 13 de octubre del mismo año. Diario Oficial de la Federacion. Cidade do México, 25 abril. Disponível em: https://bit.ly/33GP7O4. Acesso em: 22 dez. 2021. 
MÉXICO. 2011. Reglamento de la Ley de Federal de Seguridad Privada.

Diario Oficial de la Federacion. Cidade do México, 18 out. Disponível em: https://bit.ly/3piJXjE. Acesso em: 22 dez. 2021. October 18.

MÉXICO. 2014. Ley de seguridad privada para el Distrito Federal.

Gaceta Oficial del Distrito Federal. Cidade do México, 18 dez.

Disponível em: https://bit.ly/3mquTyJ. Acesso em: 22 dez. 2021.

MÉXICO. 2021. Direccíon de Seguridad de la Comisión Nacional

de Seguridad. Tarifas de los Trámites de Dirección General. Disponível em:

https://bit.ly/3EBPmqx. Accesso em 27 dec. 2021.

MÉXICO. 2021. Secretaría de la Defensa Nacional. Formatos de Pagos

E5 del 2021. [Online] 6 jan. Disponível em: https://bit.ly/3JzdnCq.

Accesso em: 27 dez. 2021.

MULLER, Markus-Michael. 2010. Private Security and the State

in Latin America: The Case of Mexico City. Brazilian Political

Science Review. Rio de Janeiro, v. 4, n. 1, pp. 131-154. (1): 131-154.

Disponível em: https://bit.ly/3yPrm1Y. Acesso em: 22 dez. 2021.

MULLER, Markus-Michael. 2016. The Punitive City: Privatized Policing and

Protection in Neoliberal Mexico. London: Zed Books.

NAGARAJ, Vijay. 2012. Mapping the Political Economy of India's Private

Security Industry. Economic and Political Weekly. Mumbai, v. 47, n. 33,

pp. 10-14. Disponível em: https://bit.ly/3egaPue. Acesso em: 22 dez. 2021.

NALLA, Mahesh; CRICHLOW, Vaughn. 2017. Have the standards for

private security guards become more stringent in the post 9/11

Era? An assessmentof security guard regulations in the US from

1982 to 2010. Security Journal. New York, v. 30, n. 2, pp. 523-537.

DOI: $10.1057 / \mathrm{sj} .2014 .21$

NALLA, Mahesh; PRENZLER, Tim. (ed.). 2018. Regulating the security industry:

Global perspectives. New York: Routledge.

NUEVO LEÓN. 2016. Permiso / Registro Autorización / Revalidación de permiso para prestar servicios de seguridad privada. Nuevo León, 16 nov. 2016. Disponível em: https://bit.ly/3qlV2j8. Acesso em: 22 dez. 2021.

NUEVO LEÓN. 2021. Ley de Seguridad Privada para el Estado de Nuevo León.

Monterrey, 17 mai.

OLSON, Mancur. 1965. The logic of collective action: Public goods and the theory of groups. Cambridge: Harvard University Press.

OSORIO, Enrique. 2016. Acusa seguridad privada patito. El Norte,

Guadalajara, 11 ago. Disponível em: https://bit.ly/30UHym2.

Acesso em: 22 dez. 2021. 
PALLARES GOMEZ, Miguel Ángel. 2014. Inseguras, empresas de seguridad privada. El Universal, [Online], 26 ago. Disponível em: https://bit.ly/3pju2BE. Acesso em: 22 dez. 2021.

PELTZMAN, Sam. 1976. Toward a more general theory of regulation. Journal of Law and Economics. Ann Arbor, v. 5, n. 2, pp. 211-240. Disponível em: https://bit.ly/3ef36g8. Acesso em: 22 dez. 2021. PERRET, Antoine. 2013. Privatization without regulation: The human risks of private military and security companies (PMSCs) in Mexico. Mexican Law Review, Cidade do México, v. 6, n. 1, pp. 163175.

Disponível em: https://bit.ly/3FpTnPW. Acesso em: 22 dez. 2021. PHILP, Mark. 2008. Peacebuilding and corruption. International Peacekeeping, Abingdon, v. 15, n. 3, pp. 310-327. DOI: $10.1080 / 13533310802058786$

PIGOU, Arthur Cecil. 1952. The Economics of Welfare. 4 ed. London: Macmillan and Company.

PLASCENCIA, Ángel. 2014. Dan contrato millonario a exempleado del fiscal. Reporte Indigo, Cidade do México, 20 ago. Disponível em: https://bit.ly/3qhzdBl. Acesso em: 22 dez. 2021.

POSNER, Richard. 1974. Theories of economic regulation. The Bell Journal of Economics and Management Science, Ann Arbor, v. 5, n. 2, pp. 335-358. DOI: $10.2307 / 3003113$

PRENZLER, Tim; SARRE, Rick. 2008. Developing a risk profile and model regulatory system for the Security Industry. Security Journal, New York, v. 21, n. 4, pp. 264-277. DOI: 10.1057/palgrave.sj.8350064

RAMIREZ, Peniley. 2014. Los socios de Genaro. Reporte Indigo, Cidade do México, 24 mar. Disponível em: https://bit.ly/3FqkfQ6. Acesso em: 22 dez. 2021.

RETIRED GOVERNMENT FUNCTIONARY. 2014. Monterrey, November 20. RETIRED PRIVATE SECURITY COMPANY OWNER. 2014. Monterrey, November 20.

REZA, Glória. 2010. De la seguridad privada a la pública. Proceso, 14 mar. Disponível em: https://bit.ly/345hUMz. Acesso em: 27 dec. 2021.

ROBERT STRAUSS CENTER. 2018. Regulating Mexico's Private Security Sector, April. Austin: Robert Strauss Center. Disponível em: https:/ / bit.ly/32kSWIn. Acesso em: 22 dez. 2021.

ROJAS MENDOZA, Raúl. 2014. Director General de Seguridad Privada y Procedimientos Sistemáticos de Operación del Distrito Federal. Mexico City, January 17.

SCHEERLINCK, Glenn; BUTS, Caroline; COOLS, Marc; RENIERS, Genserik. 2020a. The impact of regulation on private security 
industry dynamics. European Journal of Law and Economics, New York, v. 50, n. 2, pp. 223-240. DOI: 10.1007/s10657-020-09663-5

SCHEERLINCK, Glenn; BUTS, Caroline; COOLS, Mark; RENIERS, Genserik. 2020b. A private security regulation index: Ranking EU member states from 1931 until 2019. Security Journal, New York, v. 33, n. 2, pp. 266-292. DOI: 10.1057/s41284-019-00184-8 SECURITY COMPANY MANAGER. 2014. Mexico City, May 7. SECURITY COMPANY OWNER [1]. 2014. Guadalajara, October 31. SECURITY COMPANY OWNER [2]. 2014. Monterrey, November 19. SECURITY CONSULTANT [1]. 2013. Mexico City, December 9. SECURITY CONSULTANT [2]. 2014. Mexico City, April 29 and December 9. SHLEIFER, Andrei. 2005. Understanding regulation. European Financial Management, Cambridge, v. 11, n. 4, pp.439-451. Disponível em: https://bit.ly/3yOn8Yo. Acesso em: 22 dez. 2021.

SIMELANE, Hamilton Sipho. 2008. Security for All? Politics, Economy \& the Growth of Private Security in Swaziland. Review of African Political Economy, Abingdon, v. 35, n. 118, pp. 599-612. DOI: 10.1080/03056240802569276 SIN CONTROL, empresas de seguridad privada. 2014. El Universal.

[Online], 9 mar. 2014. Disponível em: https://bit.ly/3evwAqf.

Accesso em: 27 dec. 20201.

SMITH, Martin; WHITE, Adam. 2014. The paradox of security regulation:

Public protection versus normative legitimation. Policy and Politics, Oxford, v. 42, n. 3, pp. 421-437. DOI: 10.1332/030557312X655495 SOLAR, Carlos. 2018. Non-state security in Chile. Peace Review, Abingdon, v. 30, n. 2, pp. 238-245. DOI: 10.1080/10402659.2018.1458969

STATE EMPLOYEE. 2014. Area de Seguridad Privada, Consejo Estatal de Seguridad Publica de Jalisco. Guadalajara, October 8

STIERNSTEDT, Peter; BUTTON, Mark; PRENZLER, Tim; SARRE,

Rick. 2021. The 'three pillars-model of regulation': A fusion of governance models for private security. Security Journal, New York, v.34, n. 2, pp. 247-260. DOI: 10.1057/s41284-019-00224-3

STIGLER, G. 1971. The Theory of Economic Regulation. The Bell Journal of Economics and Management Science, Ann Arbor, v. 2, n. 1, pp. 3-21.

DOI: $10.2307 / 3003160$

TRANSPARENCY INTERNATIONAL. 2017. Corruptions Perceptions

Index 2016. [Online] 25 jan. Disponível em: https://bit.ly/32vb5Di. Acesso em: 22 dez. 2021.

UNGAR, Mark. 2007. The privatization of citizen security in

Latin America: From elite guards to neighborhood vigilantes. 
Social Justice. Ann Arbor, v. 34, n. 3-4, pp. 20-37. Disponível em: https://bit.ly/3plCX5O. Acesso em: 22 dez. 2021.

UNODC - UNITED NATIONS OFFICE ON DRUGS AND CRIME.

2014. State regulation concerning civilian private security and services and their contribution to crime prevention and community safety. New York:

United Nations.

WAARD, Jaap. 1999. The Private Security Industry in International

Perspective. European Journal on Criminal Policy and Research. New York,

v. 7, pp. 143-174. DOI: 10.1023/A:1008701310152

WHITE, Adam. 2010. The politics of private security: Regulation, reform and re-legitimation. New York: Palgrave MacMillan.

WHITE, Adam. 2014. Beyond the regulatory gaze? Corporate security, (in)visibility, and the modern state. In: WALBY, Kevin; LIPPERT, Randy. (ed.). Corporate security in the $21^{\text {st }}$ century: Theory and practice in international perspective. London: Palgrave Macmillan. pp. 39-55

WOOD, Jennifer; CARDIA, Nancy. 2006. Brazil. In: JONES, Trevor;

NEWBURN, Tim. (ed.). Plural policing: A comparative perspective.

New York: Routledge. pp. 139-168

ZEDNER, Lucia. 2006. Liquid security: Managing the market for crime control. Criminology E Criminal Justice, Thousand Oaks, v. 6, n. 3, pp. 267-278. DOI: 10.1177/1748895806065530 


\section{A FAILURE TO IMPOSE CONTROL: PRIVATE SECURITY AND THE MEXICAN STATE}

\section{LOGAN PUCK}

Abstract: Scholars tend to agree that imposing comprehensive regulations is one of the most effective strategies states can use to control and direct private security companies. This study shows how attempts to strictly regulate private security firms have failed in Mexico. The Federal government of Mexico, as well as each state government, has created some form of regulation to control the activities of the private security industry. In certain states, these regulations are more stringent than those in many countries. Nonetheless, corruption, weak enforcement, and high entry barriers have created low incentives for private security firms to abide by government regulations, leading to a widespread evasion and an expansive market of unregulated and undisciplined private security companies, thus bringing into question the efficacy of imposing strict private security regulations in states with weak institutions.

Key Words: Private Security; Regulations; Mexico.

\section{A FALHA EM IMPOR CONTROLE: SEGURANCGA PRIVADA E 0 ESTADO MEXICANO}

Resumo: Os estudiosos tendem a concordar que a imposição de regulações abrangentes é uma das estratégias mais efetivas que os estados podem usar para controlar e dirigir empresas de segurança privada. No entanto, este estudo mostra como as tentativas de regular estritamente as empresas de segurança privada no México têm falhado. O governo federal mexicano e todos os estados do país criaram alguma forma de regulação para controlar as atividades da indústria da segurança privada. Em alguns estados, essas regulações 
são mais rígidas do que em muitos países do mundo. No entanto, a corrupção, a fraca imposição de regras $e$ as altas barreiras à entrada de novas organizações têm criado poucos incentivos para que as empresas de segurança cumpram as regulações governamentais. Consequentemente, a evasão generalizada das regulações existentes tem criado um mercado amplo de empresas de segurança privada não reguladas e indisciplinadas, questionando, assim, a eficácia de se impor regulação estrita em Estados com instituições fracas.

Palavras-chave: Segurança Privada; Regulações; México.

Recebido: 21/05/2021 Aprovado: 11/11/2021 